Wayne State University DigitalCommons@WayneState

School of Library and Information Science Faculty

Research Publications

School of Library and Information Science

$1-1-2012$

\title{
Fallout From The E-Book Revolution
}

Robert P. Holley

Wayne State University, aa3805@wayne.edu

\section{Recommended Citation}

Holley, R. P. (2013). Fallout from the e-book revolution. The Charleston Advisor, 13(4), 55. doi:10.5260/chara.13.4.55

Available at: http://digitalcommons.wayne.edu/slisfrp/90

This Article is brought to you for free and open access by the School of Library and Information Science at DigitalCommons@WayneState. It has been accepted for inclusion in School of Library and Information Science Faculty Research Publications by an authorized administrator of DigitalCommons@WayneState. 
$\mathrm{T}$ he news is filled with the increasing importance of e-books both for libraries and consumers, but I've not seen all that much written about the radical changes that e-books will bring to library vendors. Some respected companies are most likely going to go bankrupt. Many more people, many of whom we know and like, will lose their jobs. Suppliers and institutions that libraries have come to depend upon won't be there anymore. Overall, I expect to see some major changes on the ALA exhibit floor.

Book jobbers may be the first to go. They have had a difficult time for many years surviving with razor thin margins. E-books may be the final blow. I know that most are trying to find a foothold in selling e-books, but I have my doubts that all will be successful in making the transition. Many libraries prefer to buy large packages outright or make them available for purchase through patron driven acquisitions. Purchasing individual titles either in print or as e-books has become so old school. Even for individual e-book purchases, the major players got there first and now have the technology and marketing expertise to discourage new entrants into the market. In addition, much of the expertise of the traditional book jobbers was based upon the book as physical object. They competed on service. The question was which jobber could best find difficult-to-acquire items, deliver purchases most quickly at the lowest price, and take care of any mistakes if the physical object got lost. The non-physicality of the e-book resolves many of these problems. Nothing is lost if an e-book goes astray since providing another copy has a cost that approaches zero. While jobbers will still get some business, the question is whether they will have sufficient revenues to stay in business, to keep up an acceptable level of service, and to continue their investment in technology.

A second group depends upon the physical nature of the book. Photocopiers are going the way of cell phones as users no longer need to copy physical books. Library binders face the same challenge. They have already lost much of the market for binding serials. Even those libraries that buy and keep print journals are now advised to put them in boxes since a digital counterpart is most likely available. Libraries will no longer need to bind paperbacks or provide special plastic covers. Special services such as adding spine labels and security strips will generate less revenue. In the same way, preservation of items with available digital copies will become less important. Once a book is digital, why spend money on preserving the print copy? Think about the reduction in the purchase of book-related supplies: book bins, envelopes for interlibrary loan, check out slips, and perhaps even book carts, book ends, and shelving. Finally, library architects, book moving companies, and library construction firms will have much less work as physical collections stop expanding.

The out-of-print book market also depends upon physical copies. Publishers and vendors like e-books because they aren't usually sold but rather licensed. Since the publisher or distributor retains ownership, the doctrine of first sale does not apply. The library purchaser must comply with the license terms to buy the item and will no longer be able to sell outdated and withdrawn copies. Instead, obsolete ebooks that a public library might want to withdraw will go "poof" in the ether. At some point, library revenue-generating book sales may disappear both because the library has much less to sell and because fewer people want to buy print books. In addition, libraries will no longer have much to send to the out-of-print consignment vendors such as BetterWorld Books, Blogisitcs, and Thrift Books and what they send will fetch many fewer dollars. As I have written elsewhere, price completion, lowered demand for print, and increased postage costs will put pressure on out-of-print vendors to survive. As a small book dealer, I'm expecting to sell about $1 / 3$ fewer books in 2012. Initially, the price drop will benefit libraries still interested in print; but ultimately the reduction in op vendors like the reduction in physical book stores will limit the number of places to purchase materials.

For many changes, the library is not the critical player. Publishers and proprietary vendors like Amazon, Apple, and Barnes \& Noble are looking first at selling to the public because that's where the money is. The recent flap with HarperCollins about the number of permissible uses and the decision by Penguin not to sell e-books to libraries show that publishers are willing to risk losing all sales to libraries to achieve their objectives. I am also concerned about Amazon's desire to eliminate the middleman by tempting popular authors to publish directly with them. This strategy works well for selling copies to individuals. What, however, will the public library do about circulating multiple copies of a best seller since Amazon has devised its procedures for individual sales rather than the multiple uses of library circulation? The publishers and vendors know that they supply materials in high public demand and figure quite rationally that libraries need to bend to their requirements rather than the other way around.

To conclude, I expect that the full implications of the e-book revolution will not be clearly known for the next few years. E-books, however, seem poised to take over a large share of the book market no matter what libraries and their vendors do.

\section{About the Author}

Bob Holley is a professor in the School of Library and Information Science at Wayne State University where he teaches collection development. On the side, he is a small Internet book dealer both for the fun of it and because the out-of-print book market is one of his research areas. As someone who started his library career during the relative stability of the early 1970's, he is fascinated by the rapid changes in collection development and wonders how things will eventually sort themselves out. 